Asian J. Med. Biol. Res. 2019, 5 (1), 48-51; doi: 10.3329/ajmbr.v5i1.41044

\author{
Asian Journal of \\ Medical and Biological Research \\ ISSN 2411-4472 (Print) 2412-5571 (Online) \\ www.ebupress.com/journal/ajmbr
}

\title{
Article \\ Production and compositional studies of milk in local Pabna cows of Bangladesh
}

Md. Azharul Islam Talukder ${ }^{1}$, Md. Shahjahan ${ }^{2 *}$, Md. Rezwanul Habib ${ }^{1}$, Md. Salahuddin ${ }^{2}$, Seikh Masudur Rahman $^{2}$, Md. Yousuf Ali $^{2}$, Sirazum Munira ${ }^{2}$, Md. Abu Haris Miah ${ }^{2}$, Md. Mostain Billah ${ }^{2}$, Shahidur Rahman ${ }^{2}$ and Abul Kashem Fazlul Haque Bhuiyan ${ }^{3}$

${ }^{1}$ Bangladesh Livestock Research Institute, Savar, Dhaka-1341, Bangladesh

${ }^{2}$ Bangladesh Livestock Research Institute Regional Station, Baghabari, Sirajganj-6770, Bangladesh

${ }^{3}$ Department of Animal Breeding and Genetics, Bangladesh Agricultural University, Mymensingh-2202, Bangladesh

*Corresponding author: Md. Shahjahan, BLRI Regional Station, Baghabari, Shahjadpur, Sirajganj, Bangladesh. E-mail: sajubau@gmail.com

Received: 03 March 2019/Accepted: 26 March 2019/ Published: 31 March 2019

\begin{abstract}
The Pabna is one of the potential local cattle breeds in Bangladesh regarding milk production and its nutritive quality. The aim of the study was to know the effect of lactation length, parity and management on production performance and nutritional/physiochemical composition of the milk of local Pabna cows. Besides the regular milking, 15 days' interval test day milking was recorded from 12 local Pabna cows with different lactation period (up to fifth month of calving) from BLRI Regional Station, Baghabari during JanuarySeptember, 2018. In addition, 12 and 16 milk samples $(200 \mathrm{ml} / \mathrm{sample})$ were collected from the cows raised at BLRI Regional Station and the community of Dairy Development Research Project at Bera, Pabna district during June, 2018, respectively. Data were analyzed in an ANOVA of Completely Randomized Design and independent sample $t$-test, respectively, using SAS version 9.1.3 (SAS Institute Inc., Cary, NC, USA) including Tukey's HSD post hoc test to separate means. The average daily milk yield was significantly $(p<0.05)$ higher during the first month $(4.62 \mathrm{~L})$ of lactation and the lowest value recorded at $5^{\text {th }}$ month $(3.50 \mathrm{~L})$. Among the test days milking better yield observed at 15 days $(4.79 \mathrm{~L})$ of experimental lactation period $(p<0.05)$. The effect of lactation stages and parity number had no significant variations $(p>0.05)$ on nutrient compositions of local Pabna cows' milk in both on-station and community. However, the overall characteristics of milk between onstation and community had significant differences on the composition of total solids $(p<0.001), \mathrm{SNF}(p<0.001)$, fat $(p<0.01)$, and protein $(p<0.05)$ where the highest values found as $14.81,8.65,6.17$ and $3.53 \%$ at on-station, respectively. The first month of lactation observed as best milk producing period among the five months and the management system had positive association with milk composition of local Pabna cows.
\end{abstract}

Keywords: lactation; parity; management; test day milking

\section{Introduction}

Milk is an ideal food which contains all the essential nutrients for physiological functions including carbohydrates, proteins, fats, vitamins, minerals in significant amount than any other food items of human being. Among the native cattle varieties local Pabna cows are more promising in milk production in Bangladesh (Bhuiyan et al., 2007). The study of Czerniewicz et al. (2006) revealed that physiochemical analysis is an important tool to scrutinize the quality of milk encompassing chemical composition, physical properties, microbiological and nutritive values. Several studies (Udo et al., 1990; Hoque et al., 1999; Yeasmin et al., 2017; Rahman et al., 2014) have conducted on milk yield and its compositions in Pabna cattle or their crosses but indepth study based on lactation period, parity number and a comparative management system has not conducted 
yet. Thus this study was planned to clarify the production and compositional studies of milk in local Pabna cows of Bangladesh.

\section{Materials and Methods}

\subsection{Sources of data}

The milk production was recorded from 12 local Pabna cows at the $6^{\text {th }}$ day of parturition and daily milk yield was considered for total five months' of lactation including 15 days' interval test day milking to provide special emphasize (excluding first five days). A total of 12 and 16 milk samples were collected from the cows raised at BLRI Regional Station and Dairy Development Research Project (DDRP) community at Bera, Pabna district (Source Trace System, Massachusetts, USA), respectively, for compositional studies during June, 2018.

\subsection{Management system}

Calves were separated from their mother during night to morning ( $9 \mathrm{pm}-8 \mathrm{am})$ and also morning to afternoon $(10.00 \mathrm{am}-4.00 \mathrm{pm})$. Usually before milking, the udder was washed by using warm water and dried with damp cloth. The cows had the same parity $\left(2^{\text {nd }}\right)$ and similar feeding regime (dry matter basis with $2.5 \%$ of body weight using concentrate, straw and/or green grass).

\subsection{Physiochemical analyses of milk}

To determine the nutritional composition of milk, all collected milk samples (200 ml) were shifted by ice box until analyzed at laboratory using Lactoscan MMC50 (Nova Zagora, Bulgaria).

\subsection{Data analysis}

Data on milk production and nutritional composition were statistically analysed in an ANOVA of Completely Randomized Design and independent sample $t$-test, respectively, by SAS version 9.1.3 (SAS Institute Inc., Cary, NC, USA) including Tukey's HSD post hoc test to separate means.

\section{Results and Discussion}

The average daily milk yield was significantly $(p<0.05)$ higher during the first month $(4.62 \mathrm{~L})$ of lactation and the lowest daily milk yield found at $5^{\text {th }}$ month $(3.50 \mathrm{~L})$. However, daily milk yield of Pabna cows raised at BLRI Research Station did not vary significantly $(p>0.05)$ during $3^{\text {rd }}$ and $4^{\text {th }}$ months of lactation period (Table 1$)$. Among the test days' milking (Figure 1) better yield was observed at 15 days $(4.79 \mathrm{~L})$ of experimental lactation period $(p<0.05)$. Average milk yield of local Pabna cattle from this study was $4.07 \mathrm{~kg}$ for first five-month experimental period which is lower from the findings of Rahman et al. (2014) mentioning 6.46 L at BLRI, Savar and $6 \mathrm{~L}$ at Pabna regions but agreed with the findings of Yeasmin et al. (2017) for Pabna cows. Considering other local cows the findings of Mostari et al. (2007) and Habib (2001) stated the average daily milk yield of RCC was $2.24 \mathrm{~kg}$ and $2.55 \mathrm{~kg}$, respectively, under farm condition which were lower than the present findings. The overall results are indicating the genetic potentiality of Pabna cows on milk yield including breed effects. The effect of lactation stages (up to three or above months) had no significant variations $(p>0.05)$ on nutrient compositions of local Pabna cows' milk (Table 2). Based on the effects of parity number and lactation stages of cows, similar trends $(p>0.05)$ were also found in the milk collected from community cows (Table 3). The findings of Yeasmin et al. (2017) revealed $9.67 \%$ SNF, $4.01 \%$ fat, $3.65 \%$ protein, $4.95 \%$ lactose and $0.65 \%$ ash in the milk of local Pabna cows which were comparatively higher in our study. According to other local cows, the RCC produced lower amount of milk but their milk contained a higher percentage of fat (about $6 \%$ ) which was almost similar to present findings for Pabna cows' milk. The overall characteristics of milk considering management system between on-station and community had significant differences on the composition of total solids $(p<0.001)$, SNF $(p<0.001)$, fat $(p<0.01)$, and protein $(p<0.05)$ where the highest values were $14.81,8.65,6.17$ and $3.53 \%$ at on-station cows' milk, respectively (Table 4). Rahman et al. (2014) observed $9.94 \%$ SNF, $5.05 \%$ fat and $3.78 \%$ protein from local cows where the values were 9.76, 4.64 and 3.70\% from BLRI, Savar, and 9.75, 4.07 and 3.70\% from the local Pabna cows from the rural areas at Pabna district of Bangladesh. 
Table 1. Effect of lactation period on daily milk yield of local Pabna cows at BLRI RS on-station.

\begin{tabular}{llllll}
\hline Lactation period (month) & n & LSM \pm SE (litre) & Min & Max & P value \\
\hline First & 390 & $4.62 \pm 0.04^{\mathrm{a}}$ & 2.79 & 10.85 & \\
Second & 360 & $4.14 \pm 0.04^{\mathrm{b}}$ & 2.57 & 6.51 & \\
Third & 300 & $3.86 \pm 0.05^{\mathrm{c}}$ & 2.33 & 5.68 & 0.000 \\
Fourth & 270 & $3.72 \pm 0.05^{\mathrm{c}}$ & 2.44 & 5.43 & \\
Fifth & 150 & $3.50 \pm 0.07^{\mathrm{d}}$ & 2.33 & 4.98 & \\
Overall & 1470 & $4.07 \pm 0.02$ & 2.33 & 10.85 & \\
\hline
\end{tabular}

Mean values bearing different letters $(\mathrm{a}, \mathrm{b}, \mathrm{c}$ or $\mathrm{d})$ in each row are significantly different $(p<0.05)$

Table 2. Effect of parity and lactation stages on milk characteristics of local Pabna cows at on-station.

\begin{tabular}{|c|c|c|c|c|c|c|}
\hline \multirow[t]{2}{*}{ Parameters } & \multicolumn{2}{|c|}{ Parity number $($ Mean \pm SE) } & \multirow[t]{2}{*}{$t$ test } & \multicolumn{2}{|c|}{ Lactation stage (Mean \pm SE) } & \multirow[t]{2}{*}{$t$-test } \\
\hline & $\leq 2$ parity $(n=12)$ & $>2$ parity $(n=0)$ & & $\leq 3$ months $(n=9)$ & $>3$ months $(n=3)$ & \\
\hline Total solid (\%) & $14.81 \pm 0.19$ & - & - & $14.85 \pm 0.24$ & $14.70 \pm 0.37$ & 0.756 \\
\hline SNF $(\%)$ & $8.65 \pm 0.08$ & - & - & $8.68 \pm 0.09$ & $8.55 \pm 0.16$ & 0.512 \\
\hline Fat $(\%)$ & $6.17 \pm 0.16$ & - & - & $6.17 \pm 0.20$ & $6.15 \pm 0.26$ & 0.958 \\
\hline Protein $(\%)$ & $3.53 \pm 0.11$ & - & - & $3.51 \pm 0.10$ & $3.59 \pm 0.38$ & 0.768 \\
\hline Lactose (\%) & $4.45 \pm 0.09$ & - & - & $4.49 \pm 0.10$ & $4.30 \pm 0.18$ & 0.365 \\
\hline $\operatorname{Ash}(\%)$ & $0.68 \pm 0.01$ & - & - & $0.68 \pm 0.02$ & $0.67 \pm 0.04$ & 0.829 \\
\hline Specific gravity & $1.027 \pm 0.001$ & - & - & $1.027 \pm 0.001$ & $1.026 \pm 0.001$ & 0.382 \\
\hline $\mathrm{pH}$ & $6.72 \pm 0.01$ & - & - & $6.71 \pm 0.02$ & $6.73 \pm 0.01$ & 0.720 \\
\hline Conductivity & $4.04 \pm 0.04$ & - & - & $4.09 \pm 0.03$ & $4.13 \pm 0.03$ & 0.504 \\
\hline
\end{tabular}

Table 3. Effect of parity and lactation stages on milk compositional characteristics from local Pabna cattle at community.

\begin{tabular}{|c|c|c|c|c|c|c|}
\hline \multirow[t]{2}{*}{ Parameters } & \multicolumn{2}{|c|}{ Parity number $($ Mean \pm SE) } & \multirow[t]{2}{*}{$t$-test } & \multicolumn{2}{|c|}{ Lactation stage $($ Mean \pm SE) } & \multirow[t]{2}{*}{$t$-test } \\
\hline & $\leq 2$ parity $(n=10)$ & $>2$ parity $(n=6)$ & & $\leq 3$ months $(n=5)$ & $>3$ months $(n=11)$ & \\
\hline Total solid (\%) & $13.91 \pm 0.51$ & $12.97 \pm 0.35$ & 0.211 & $13.55 \pm 0.66$ & $13.55 \pm 0.44$ & 1.00 \\
\hline $\operatorname{SNF}(\%)$ & $7.88 \pm 0.18$ & $8.05 \pm 0.10$ & 0.493 & $7.80 \pm 0.27$ & $7.99 \pm 0.13$ & 0.487 \\
\hline Fat $(\%)$ & $6.04 \pm 0.51$ & $4.92 \pm 0.39$ & 0.150 & $5.75 \pm 0.68$ & $5.56 \pm 0.46$ & 0.822 \\
\hline Protein $(\%)$ & $3.10 \pm 0.07$ & $3.15 \pm 0.04$ & 0.515 & $3.07 \pm 0.09$ & $3.13 \pm 0.05$ & 0.507 \\
\hline Lactose $(\%)$ & $4.15 \pm 0.10$ & $4.25 \pm 0.06$ & 0.472 & $4.11 \pm 0.15$ & $4.22 \pm 0.07$ & 0.481 \\
\hline $\operatorname{Ash}(\%)$ & $0.63 \pm 0.02$ & $0.64 \pm 0.01$ & 0.546 & $0.62 \pm 0.02$ & $0.64 \pm 0.01$ & 0.433 \\
\hline Specific gravity & $1.025 \pm 0.001$ & $1.027 \pm 0.001$ & 0.228 & $1.025 \pm 0.001$ & $1.025 \pm 0.001$ & 0.607 \\
\hline $\mathrm{pH}$ & $6.81 \pm 0.06$ & $6.77 \pm 0.09$ & 0.669 & $6.80 \pm 0.07$ & $6.80 \pm 0.07$ & 0.987 \\
\hline Conductivity & $4.13 \pm 0.03$ & $4.14 \pm 0.12$ & 0.863 & $4.17 \pm 0.07$ & $4.11 \pm 0.02$ & 0.272 \\
\hline
\end{tabular}

Table 4. The overall milk compositional characteristics of local Pabna cows ( $\leq 2$ parity) raised under onstation and community.

\begin{tabular}{llll}
\hline Parameters & \multicolumn{2}{c}{ Management systems (Mean \pm SE) } & \multirow{t}{*}{-test } \\
\cline { 2 - 3 } & On-station $(\mathbf{n = 1 2})$ & \multicolumn{1}{c}{ Community $(\mathbf{n = 1 0})$} & 0.000 \\
\hline Total solid (\%) & $14.81 \pm 0.19$ & $12.97 \pm 0.19$ & 0.000 \\
SNF (\%) & $8.65 \pm 0.08$ & $8.05 \pm 0.10$ & 0.003 \\
Fat (\%) & $6.17 \pm 0.16$ & $4.92 \pm 0.39$ & 0.034 \\
Protein (\%) & $3.53 \pm 0.11$ & $3.15 \pm 0.04$ & 0.162 \\
Lactose (\%) & $4.45 \pm 0.09$ & $4.25 \pm 0.06$ & 0.099 \\
Ash (\%) & $0.68 \pm 0.01$ & $0.64 \pm 0.01$ & 0.702 \\
Specific gravity & $1.027 \pm 0.001$ & $1.027 \pm 0.001$ & 0.438 \\
pH & $6.72 \pm 0.01$ & $6.77 \pm 0.10$ & 0.411 \\
Conductivity & $4.10 \pm 0.02$ & $4.14 \pm 0.05$ & \\
\hline
\end{tabular}




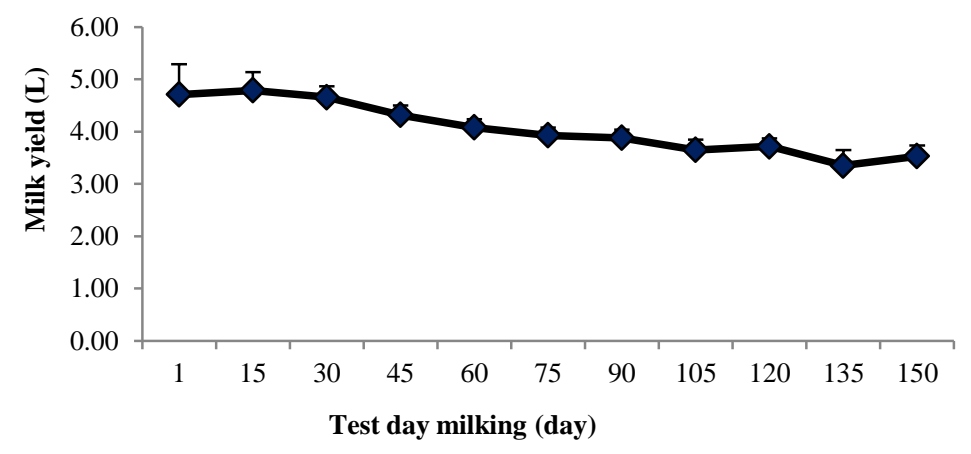

Figure 1. Milk yield of local Pabna cows in different test days of lactation.

\section{Conclusions}

It is concluded that first month of lactation was the best milk producing period among the five months and the management system had positive association with milk composition of local Pabna cows.

\section{Acknowledgements}

The authors are grateful to the Dairy Development Research Project of Bangladesh Livestock Research Institute for required funding to conduct this research work.

\section{Conflict of interest}

None to declare.

\section{References}

Bhuiyan AKFH, MM Hossain and GK Deb, 2007. Indigenous cattle genetic resources of Bangladesh and a way forward to their development. Bangladesh J. Prog. Sci. Tech., 5: 105-112.

Czerniewicz M, K Kielczewska and A Kruk, 2006. Comparison of some physicochemical properties of milk from Holstein-Friesian and Jersey cows. Polish J. Food and Nutr. Sci., 15: 61-64.

Habib A, 2001. Study on the Red Chittagong cattle-an animal genetic resource of Bangladesh. M S thesis. Department of Animal Breeding and Genetics. BAU, Mymensingh 2202.

Hoque MA, MR Amin and MS Hussen, 1999. Dairy potential of Pabna cows and crossbreds with Sahiwal and Friesian and within-and between-breed sire effects. Asian Australas. J. Anim. Sci., 12: 61-164.

Mostari MP, KS Huque, MS Hasanat and Z Gulshan, 2007 Productive and reproductive efficiency of Red Chittagong cattle under farm condition. Prog. Agri., 18: 109-114.

Rahman MM, MAA Mahmud, MA Baset, SU Mahfuz, H Mehraj and AFMJ Uddin, 2014. Milk nutritional composition in relation to cow genotype and location of Bangladesh. Int. J. Busi., Soc. Sci. Res., 1: 155-160.

Udo HMJ, C Hermans and F Dawood, 1990. Comparison of two cattle production systems in Pabna district Bangladesh. Trop. Anim. Heal. Prod., 22: 247-259. 